прогулянках, екскурсіях тощо. Для батьків колективом закладу проводяться батьківські збори, круглі столи, анкетування, індивідуальне консультування, Дні відкритих дверей, організовуються спільні свята і спортивні розваги, конкурси, створено консультативний пункт. Тематика зустрічей найрізноманітніша, наприклад, «Дитячий куточок вдома», «У центрі уваги - особистість», «Адаптація дітей у колективі», «Дитячі страхи: причини та наслідки», «Фізичне виховання в сім'ї», «Розуміємо ми дитину?», «Місце батька у вихованні дитини», «Готовність до навчання у школі». Працює консультативний пункт відповідно до складеного графіка роботи чотири рази на тиждень, індивідуальні консультації батьки можуть отримати за потребою у зручний для них час. Консультування батьків або осіб, які їх замінюють, може проводитись одним або декількома спеціалістами одночасно. Консультують батьків за попередньо складеним планом, який передбачає проведення організаційно-педагогічної роботи, методичної роботи, забезпечую дотримання зовнішніх зв'язків із психологічною службою, взаємодію зі школою, медичною службою тощо. Фіксація діяльності здійснюється у журналі звернень батьків.

Водночас, практика свідчить про те, що контакт між вихователями дошкільних навчальних закладів та вчителями початкових класів $є$ недостатнім, поверховим, іноді формальним. Важливим завданням на сучасному етапі є створення інформаційного поля із забезпечення та досягнення наступності етапів освіти. Сучасний дошкільний навчальний заклад освіти за умов оптимального використання його можливостей може розв'язати проблеми сучасної підготовки п'ятирічок до шкільного навчання за режимом та в обсязі, якій найбільше влаштовує і дитину, i батьків. Щоб забезпечити реальну перспективність $\mathrm{i}$ наступність у роботі дошкільної та початкової ланок освіти, надати дітям, які відвідують ДНЗ та не відвідують їх, рівних стартових можливостей здобуття передшкільної освіти, важливо дотримуватись певних умов: співробітництво має бути довготривалим i нерозривним, робота - системною і плановою, завдання - комплексним та інтегрованим.

\title{
Література
}

1. Інструктивно-методичні рекомендації «Про забезпечення взаємодії в освітній роботі з дітьми старшого дошкільного і молодшого шкільного віку» (Лист МОНмолодьспорту України від 19.08.2011 р. № 1/9-634) // Дошкільне виховання. - 2011. - № 9. - С.4-6. 2. Крайнова Л. До проблем наступності між дошкільним навчальним закладом і школою / Л. Крайнова // Дошкільна освіта. - 2010. - № 1. - С. 11-17. 3. Курчатова А. Скоро до школи. Забезпечення наступності між дошкільною та початковою освітою / А. Курчатова, С. Медвєдєва // Дошкільне виховання. - 2012. - № 8. - С.23-24. 4. Назаренко Г. І. Організаційно-педагогічні умови забезпечення наступності в навчанні дітей дошкільного та молодшого шкільного віку: автореф. дис. на здобуття наукового ступеня канд. пед. наук: спец. 12.00 .09 «Теорія навчання» / Г. І. Назаренко. - Кривий Ріг, 2002. 20 с. 5. Савченко О. Я. Наступність і перспектива в роботі двох перших ланок освіти / О. Я. Савченко // Дошкільне виховання. - 2000. - №11. - С. 4-5.

УДК 378.6.091.2:37

Я. В. Топольник, кандидат пед. наук, ст. викладач, Донбаський державний педагогічний університет

\section{ВИВЧЕННЯ СПЕЦКУРСУ «ОСНОВИ НАУКОВОЇ ОРГАНІЗАЦІЇ НАВЧАЛЬНОЇ ПРАЦІ СТУДЕНТІВ» ЯК УМОВА ЕФЕКТИВНОСТІ НАВЧАЛЬНОГО ПРОЦЕСУ}

Топольник Я. В. Вивчення спецкурсу «Основи наукової організації навчальної праці студентів» як умова ефективності навчального процесу.

У статті розглянуто аспекти проблеми наукової організації навчальної праці студентів педагогічного ВНЗ. Зазначено, що вимоги НОП охоплюють усі сторони життя студентів як у сфері навчально-пізнавальної діяльності, так і у сфері вільного часу. Доведено, що майбутні вчителі повинні оволодіти основами наукової організації педагогічної праці, уміннями НОП школярів. Звертається увага на те, що кращого результату навчання можна досягти за умови поєднання спеціального курсу щодо формування навчальних умінь 3 викладанням конкретних предметів психолого-педагогічного циклу. Подаються основні положення програми розробленого автором 
спецкурсу.

Ключові слова: спецкурс, наукова організація праці, навчальна праця, знання, уміння, навички, майбутній вчитель.

Топольник Я. В. Изучение спецкурса «Основы научной организации учебного труда студентов» как условие эффективности учебного процесса.

В статье рассмотрены аспекты проблемы научной организации учебного труда студентов педагогического вуза. Указано, что требования НОТ охватывают все стороны жизни студентов как в сфере учебно-познавательной деятельности, так и в сфере свободного времени. Доказано, что будущие учителя должны овладеть основами научной организации педагогического труда, умениями НОТ школьников. Обращается внимание на то, что лучшего результата обучения можно достичь при условии сочетания специального курса по формированию учебных умений с преподаванием конкретных предметов психолого-педагогического цикла. Представлены основные положения программы разработанного автором спецкурса.

Ключевые слова: спецкурс, научная организация труда, учебный труд, знания, умения, навыки, будущий учитель.

Topol'nik Y. V. Learning of special course «Basics of scientific organization of students' academic work» as a condition of the effectiveness of educational process.

In the article considers aspects of the problem of scientific organization of educational work of students of pedagogical university. Indicated that the requirements of scientific organization of work cover all aspects of life as in the field of learning activities of students, as and in their free time. It is noted that future teachers should master the basics of the scientific organization of pedagogical work, skills of scientific organization of work schoolchildren. Attention is drawn to the fact that the best learning results can be achieved with provided by a combination of the formation of a special study course of training skills to the teaching of specific subjects of psycho-pedagogical cycle. The main provisions of the program developed by the author of the special study course.

Key words: special study course, scientific organization of educational work, educational work, knowledge, competencies, skills, future teacher.

Реформування концептуальних, структурних i організаційних засад освітянської системи України вимагає підготовки нового покоління педагогічних кадрів, здатного до роботи в інших соціально-економічних, політичних умовах. Останнім часом здійснюються активні пошуки нових педагогічних технологій підготовки майбутнього спеціаліста, які зорієнтовані на формування особистості, розвитку його творчості й самостійності. Ідеться про розроблення нової концепції навчання, де всі пї складові спрямовані на особистісно орієнтований розвиток майбутнього фахівця, формування його як творця, здатного не лише самостійно здобувати знання, а й реалізувати їх відповідно до практичних вимог сьогодення. Важлива роль у цьому складному процесі належить науковій організації праці студентів.

У широкому сенсі під науковою організацією праці слід розуміти сукупність всієї діяльності студентів як в навчальній аудиторії, так і поза нею, в контакті з викладачем і за його відсутності.

Основне завдання вищої освіти полягає у формуванні творчої особистості фахівця, здатного до саморозвитку, самоосвіти, інноваційної діяльності. Розв'язання цього завдання навряд чи можливо тільки шляхом передачі знань в готовому вигляді від викладача до студента. Необхідно перевести студента 3 пасивного споживача знань в активного їх творця, що вміє сформулювати проблему, проаналізувати шляхи ії рішення, знайти оптимальний результат і довести його правильність.

Проблему наукової організації навчальної праці послідовно висвітлювали педагоги і психологи: О. Аніщенко, Ю. Бабанський, В. Давидов, О. Дмитрієв, Л. Занков, Є. Кабанова-Меллер, Н. Кузьміна, 3. Курлянд, І. Лернер, А. Мудрик, Н. Наумова, К. Платонов, І. Раченко, М. Скаткін, С. Скидан, В. Сластьонін, М. Черпинський, Г. Щукіна та інші.

У 60-х роках співробітниками відділу організації народної освіти і школознавства 
Науково-дослідного інституту педагогіки УРСР було здійснено спробу визначити зміст курсів 3 наукової організації праці (НОП) для педагогічних інститутів, училищ i загальноосвітніх шкіл [4, с. 4].

Орієнтовну тематику курсу 3 НОП для майбутніх педагогів було розроблено М. Черпинським (1966р.). Викладання такого курсу визнавалося за доцільне після вивчення студентами педагогіки, психології, гігієни, фізіології, політичної економії. Орієнтовна програма курсу з НОП сприяла підготовці майбутніх вчителів до реалізації заходів з НОП учнів. Водночас слід визначити одним із ії недоліків незначний обсяг (особливо - практичної частини), відсутність рекомендованої літератури психологопедагогічного спрямування [2, с. 66].

Наприкінці 60-х років порушувалося питання щодо введення до навчальних планів закладів педагогічної освіти окремого предмету «Основи НОП». Також у цей період планувалося здійснити відповідну підготовку й перепідготовку педагогічних кадрів у галузі наукової організації педагогічної праці. Радою Педагогічного товариства УРСР вносилася пропозиція щодо оголошення конкурсу на складання навчальних посібників 3 НОП у відповідності до чинних програм для педагогічних ВНЗ, а також шкіл [2, с. 68].

Наприкінці 70-х років актуалізувалося питання удосконалення всієї загальноосвітньої системи і передусім методів навчання, підготовки учнів до «життя й праці», а також підвищення якості підготовки педагогів. Це дало поштовх до розробки орієнтовної навчальної програми спецкурсу для студентів педагогічних навчальних закладів «Основи наукової організації педагогічної праці» (НОПП) [5]. Її мета полягала у прискоренні адаптації студентів до навчання у ВН3, покращенні їхньої підготовки у галузі організаторів навчання й виховання учнів у школі.

Отже, на сучасному етапі розвитку освіти відсутня достатня кількість наукових праць 3 досліджень проблеми розробки програм та вивчення спецкурсу 3 основ наукової організації навчальної праці студентів, тому дана проблема $є$ актуальною та потребує уваги з боку науковців.

Mета статті полягає в обгрунтуванні значення вивчення спецкурсу «Основи наукової організації навчальної праці студентів» у поєднанні з викладанням дисциплін психологопедагогічного циклу як умови ефективності навчального процесу у педагогічному виші та майбутньої професійної діяльності.

Наукова організація праці (НОП) студента - це вивчення й організація праці, що грунтується на основних положеннях педагогіки, психології, фізіології стосовно вимог до діяльності студента, ураховує можливості та вікові особливості його організму і створює сприятливі умови для розвитку. Вимоги НОП охоплюють усі сторони життя студентів як у сфері навчально-пізнавальної діяльності, так і у сфері вільного часу.

Провідною діяльністю студентів у вищих навчальних закладах (ВН3) є навчальна. Вона полягає у мотивованій активності в процесі досягнення цілей навчання. Навчальна діяльність студентів на відміну від навчальної діяльності учнів має професійну спрямованість. Суттєвим у їхній навчальній діяльності також $є$ посилення ролі професійних мотивів самоосвіти та самовиховання.

Наукова організація праці студентів педагогічних ВНЗ має подвійний характер, оскільки майбутні вчителі повинні не лише засвоїти головні принципи навчальної діяльності, а й оволодіти основами наукової організації педагогічної праці, уміннями НОП школярів. Складовими НОП студента $є$ уміння визначати мету своєї діяльності та шляхи ії реалізації, планувати процес діяльності, контролювати їі результати і відповідно до цього намічати подальшу самоосвітню діяльність.

Особливості діяльності студента яскраво проявляються вже на першому курсі. Перехід від навчання в середній школі до навчання у виші характеризується різкою зміною умов, в яких здійснюється діяльність. Змінюється навчальний матеріал, викладацький склад, відбувається зміна оточуючого середовища в аудиторії, навчальному закладі, по місцю проживання і т.д. Всі зміни певним чином впливають на психічний стан тих, хто 
навчається, і в кінцевому випадку впливають на хід навчальної та суспільної діяльності.

Вирішенню вказаної проблеми сприятиме вивчення основ наукової організації праці студентів вишу, що вможливить організацію навчальної та позанавчальної діяльності на наукових засадах за рахунок індивідуалізації навчально-виховного процесу із урахуванням анатомо-фізіологічних, психофізіологічних, вікових та інших особливостей, створення сприятливих умов праці, раціонального використання часу і використання навчально-методичних та інших ресурсів.

Зазначимо, що не існує жодної думки про шляхи навчання навчальній праці на істинно наукових основах. Важливо, що в сучасній практиці відсутні наукові засади формування досвіду організації навчальної праці студента. Вивчення значної кількості літератури 3 даної проблеми свідчить про поодинокі випадки, коли в окремих навчальних закладах розроблені методичні рекомендації щодо організації самостійної роботи студентів при вивченні окремих дисциплін чи спецкурсів. Отже, з одного боку, як свідчить практика, навчання може здійснюватися лише під час викладання конкретних навчальних дисциплін, оскільки навчальні вміння формуються на конкретному змісті. 3 іншого, не виключена можливість навчання вмінню вчитися у процесі опанування спеціальним курсом. Наш досвід переконує: кращого результату можна досягти за умов приведення у відповідність навчання вмінню вчитися (організувати навчальну працю) на основі поєднання спеціального курсу щодо формування навчальних умінь при викладанні конкретних предметів психолого-педагогічного циклу.

Зміст розробленого автором спецкурсу «Основи наукової організації навчальної праці студентів» відповідає сучасним вимогам, сприяє поглибленню науково-теоретичних знань майбутніх учителів і формуванню практично спрямованої педагогічної компетенції. Метою спецкурсу є підготовка майбутніх учителів до професійно-педагогічної діяльності у загальноосвітніх школах і навчальних закладах через формування досвіду наукової організації навчальної праці, що сприятиме розвиткові культури розумової праці майбутнього вчителя, його критичного мислення та педагогічної творчості. Спецкурс розраховано на 36 год.: 6 год. - лекційні заняття, 12 год. - практичні, самостійна робота 18 год. [3].

Завданнями даного спецкурсу автор визначає наступні:

1. Розширення та поглиблення професійно-педагогічних знань студентів на основі самостійного вивчення навчальної літератури та наукових досліджень вітчизняних i зарубіжних учених 3 проблем наукової організації навчальної праці.

2. Формування у студентів навичок організації самостійної праці на наукових засадах, iii планування, організації навчального та позанавчального часу, робочого місця.

3. Ознайомлення з психофізіологічними умовами продуктивності самостійної праці.

4. Вироблення у майбутніх учителів умінь і навичок конспектування та методичного опрацювання тексту лекції, самостійно, творчо й грамотно опрацьовувати навчальну та методичну літературу, періодичні видання і першоджерела, складати рецензії, анотації та резюме, готувати на їхній основі реферати і доповіді.

5. Озброєння студентів правилами роботи в бібліографічному відділі та 3 пошуковими системами в мережі Інтернет.

6. Розширення знань майбутніх учителів про прийоми раціонального опрацювання навчального матеріалу.

7. Сформувати у студентів навички у підготовці до семінарських і лабораторнопрактичних занять, публічного виступу, його оцінки та самооцінки, формування умінь вільно володіти навчальним матеріалом, брати участь у дискусіях та інших активних формах роботи.

8. Формування у студентів умінь і навичок підготовки до заліків та екзаменів, конструювання відповіді під час їх складання.

9. Вироблення у майбутніх умінь і навичок самостійного науково-педагогічного пошуку, організації експериментально-дослідної роботи, критичного ставлення до 
педагогічного досвіду.

10. Розвиток умінь в організації самоосвіти, професійного вдосконалення, творчого мислення майбутнього учителя як основи новаторської педагогічної майстерності.

Запропонована програма розрахована на студентів вищих педагогічних навчальних закладів, кураторів, класних керівників, викладачів та вчителів-предметників, усіх, хто цікавиться ефективною організацією навчальної праці на наукових засадах.

Для більш ефективного оволодіння студентами навчальних дій на першому занятті спецкурсу «Основи наукової організації навчальної праці студентів» була рекомендовано «Пам'ятку», що включала перелік раціональних прийомів конспектування, склад основних розумових операцій щодо сприйняття i смислової переробки навчальної інформації. На заняттях спецкурсу ми відпрацьовували прийоми розумових операцій (заміна декількох понять одним, яке належить до більш високого рівня абстрагування, використання об'ємних в інформаційному відношенні символів, економних лаконічних форм запису, особлива увага приділялась використанню під час конспектування різних поміток і позначок, підкреслень тощо).

Частково ці питання вивчалися в межах конкретних дисциплін психологопедагогічного циклу: «Вступ до спеціальності», «Педагогіка», «Управління навчальною діяльністю», «Основи педагогічної майстерності», «Загальна психологія», «Вікова i педагогічна психологія». Якщо, наприклад, під час спецкурсу формувалися вміння самостійно працювати 3 першоджерелами, конспектувати, готувати повідомлення і виступати $з$ ним, слухати інших і усвідомлювати навчальний матеріал, то на заняттях 3 педагогіки систематично студентам пропонувалися спеціальні завдання, спрямовані на здійснення формуючих навчальних дій, усвідомлення змісту навчального матеріалу та його опрацювання. Наведемо приклади таких завдань: виділіть основні твердження у змісті навчального заняття; виділіть найважливіші факти, теоретичні оцінки; поетапно проаналізуйте і узагальніть основні твердження занять; поділіть зміст заняття на смислові частини і дайте їм назву; складіть розгорнутий план навчального заняття; викладіть основні твердження змісту у формі тез; визначте і зафіксуйте моменти логічного завершення одного питання і перехід до наступного; спробуйте вести розумовий діалог під час заняття, помічайте ті твердження, з якими ви не погоджуєтеся, які викликають бажання посперечатися, заперечити тощо.

Упровадження у практику роботи вишу спеціального курсу «Основи наукової організації навчальної праці студентів», мета якого - підвищення якості навчальних умінь i навичок студентів, свідчать про його досить великі можливості щодо формування навичок навчальної роботи і надання відповідної методичної допомоги студентам у самостійному оволодінні умінням ефективно вчитися. Такий спецкурс надає відомості про навчальну працю в узагальненому, систематизованому вигляді й дозволяє проілюструвати ï на різноманітному конкретному матеріалі 3 окремих дисциплін. Зазначимо, що відомості про навчальну працю дозволяють 3'ясувати узагальнюючий зміст навчальних дій повніше й глибше. Спецкурс надає також можливість цілеспрямованого відпрацювання окремих навчальних дій, доведення їх до рівня навчальних умінь i навичок, що, у свою чергу, становить основу результативності навчального процесу у виші.

\section{Література}

1. Аніщенко О. В. Наукова організація праці учнів і педагогів в історії загальноосвітньої школи України : [навчальна програма спецкурсу] / Олена Валеріївна Аніщенко. - Ніжин : МІЛАНІК, 2008. - 19 с. 2. Аніщенко О. В. Спецкурси з наукової організації праці у професійній підготовці вчителів: історія та сьогодення / Олена Валеріївна Аніщенко // Nastolení moderní vědy 2008: materiály IV Mezinárodní vědecko-praktická conference (27.09. - 05.10.2008, M. Дніпропетровськ - м. Прага (Чехія). - Praha : «Publishing House Education and Science» s.r.o., 2008. - Dil. 5. Pedagogika. - C. 66 - 70. 3. Бойко Я. В. Основи наукової організації навчальної праці студентів : програма спецкурсу / Яна Володимирівна Бойко. - Слов'янськ : Видавничий центр СДПУ, 2010. - 26 с. 4. Вивчення основ наукової організації праці у педагогічному вузі // Радянська 
школа. - 1966. - №5. - С. 44-50. 5. Программы педагогических институтов. Основы научной организации педагогического труда : спецкурс. - М. : УМС при МП, 1982. - 23 с.

\section{ФОРМУВАННЯ В ДОШКІЛЬНИКІВ ЦІННІСНОГО СТАВЛЕННЯ ДО СВОЇХ БАЗОВИХ ОБОВ'ЯЗКІВ ЯК ПСИХОЛОГО-ПЕДАГОГІЧНА ПРОБЛЕМА}

Тукач I. І. Формування в дошкільників ціннісного ставлення до своїх базових обов'язків як психолого-педагогічна проблема.

У статті проаналізовано стан дослідження проблеми формування ціннісного ставлення дітей дошкільного віку до своїх базових обов'язків шляхом окреслення базових понять «мораль», «обов'язок» «ціннісне ставлення» у психолого-педагогічній літературі.

Ключові слова: дошкільник, обов'язок, мораль, ціннісне ставлення.

Тукач И. И. Формирование у дошкольников ценностного отношения к своим базовым обязанностям как психолого-педагогическая проблема.

В статье проанализировано состояние исследования проблемы формирования ценностного отношения детей дошкольного возраста к своим базовым обязанностям путем определения базовых понятий «мораль», «обязанность», «ценностное отношение» в психолого-педагогической литературе.

Ключевые слова: дошкольник, обязанность, мораль, ценностное отношение.

Tukach I. I. Forming preschoolers valuable attitude to their basic duties as psycho-pedagogical problem.

The article analyzes the research on the formation of value treatment of preschool children with their basic responsibilities by outlining the basic concepts of «morality», «duty», «value treatment» in psychological and pedagogical literature.

Key words: preschool, duty, morality, value treatment.

Кожна людина, особливо в дитинстві, потребує любові та піклування, доброзичливого ставлення до себе, відчуття своєї необхідності, значущості, прийняття і розуміння нею необхідності існування прав та обов'язків у процесі життєдіяльності. Ці чинники впливають на повноцінний особистісний розвиток дитини, моральних, правових та етичних норм пї поведінки.

Відомо, що обов'язки виникають не з народження людини, а поступово, в процесі становлення в онтогенезі та включення індивіда в суспільні відносини, пов'язані 3 виконанням рольових зобов'язань, зумовлених віком, місцем особистості в системі цих відносин.

У філософській, педагогічній, психологічній літературі зміст поняття «обов’язок» розкривається у різноманітних смислах.

У тлумачному словнику української мови зазначено, що «обов'язок - це те, що підлягає безумовному виконанню внаслідок суспільних вимог або внутрішніх стимулів; певний обсяг роботи, справ, що визначається званням, посадою тощо» [12, с. 210].

У сучасному суспільстві обов'язки переважають у таких соціальних інститутах, як моральність і право. За висловом В. Перевалова, обов'язки поділяються на природні, носіями яких виступають людина і суспільство, та юридичні, носіями яких є громадяни, держава, iї органи. Природні обов'язки відповідають основним природним правам людини $[14$, с. $502-503]$.

К. Ушинський розглядав обов'язок як умову успішної навчальної діяльності. Він рекомендував учителям із перших уроків привчати дитину полюбити свої обов'язки i 